\title{
LETTERS
}

\section{Comparing VA to Non-VA Care}

\author{
William B. Weeks, MD, PhD, MBA \\ The Dartmouth Institute, Lebanon, NH, USA. \\ J Gen Intern Med 32(2):150-1 \\ DOI: $10.1007 / \mathrm{s} 11606-016-3893-x$ \\ (C) Society of General Internal Medicine 2016
}

flawed by non-reciprocal recording biases. If, for instance, a veteran obtains a screening colonoscopy in a private sector facility, the VA records that a colonoscopy was completed and gets "credit" for it. In 2009, $66 \%$ of older, dual-eligible VA primary care users in 15 VISNs obtained their colonoscopies outside the VA. ${ }^{3}$ Because the veteran population is relatively small, however, non-VA providers may "capture" very little care performed within the VA. Furthermore, in several studies examining longer-term outcomes, patients in "VA care" might have obtained much of their follow-up care outside the VA. To fairly compare VA to non-VA care, studies with longer-term follow-up should have compared veterans who received only VA care to non-VA users; none did.

Several studies lacked relevance. One paper compared VAusing and non-VA patients only on the non-VA care they received. ${ }^{4}$ Another compared rates of decline in risk-adjusted quality indicators, but not VA to non-VA care. ${ }^{2}$ One examined survey data asking about infection prevention practices among a subset of VA and non-VA hospitals. ${ }^{5}$

Only six articles used national data to compare risk-adjusted outcomes that might be important to veterans and plausibly associated with VA or non-VA care: five indicated that VA care was worse or worsening (though not necessarily statistically so), and the one in which VA care was "mixed" was replicated with data from a year later indicating that VA care was worse (Table 1).

The review hardly demonstrates that VA care is better than nonVA care.

process indicators, but since many veterans using VA services also obtain care outside the VA, these comparisons can be

Table 1 National Studies Comparing Risk-Adjusted Outcomes that Might Be Important to Veterans and Were Plausibly Directly Related to Care Provided Within the VA

\begin{tabular}{|c|c|c|c|}
\hline $\begin{array}{l}\text { Author } \\
\text { (year) }\end{array}$ & $\begin{array}{l}\text { Data } \\
\text { years }\end{array}$ & $\begin{array}{l}\text { Risk-adjusted } \\
\text { outcome measure }\end{array}$ & Findings \\
\hline Fihn, SD (2009) ${ }^{6}$ & $2000-2005$ & $\begin{array}{l}\text { Adjusted odds of death within } 30 \text { days } \\
\text { of admission for acute myocardial } \\
\text { infarction relative to all private sector } \\
\text { hospitals }\end{array}$ & $\begin{array}{l}\text { Though results were not statistically } \\
\text { different, odds of VA mortality were } \\
\text { slightly higher and worsening over time }\end{array}$ \\
\hline Bilimoria, KY (2007) ${ }^{7}$ & $1985-2004$ & $\begin{array}{l}\text { 60-day mortality after pancreatectomy } \\
\text { (because follow-up care might have } \\
\text { been provided in both VA and non-VA } \\
\text { settings, } 3 \text {-year survival rates are ignored) }\end{array}$ & $\begin{array}{l}\text { Though results were not statistically } \\
\text { different, } 60 \text {-day VA mortality rates } \\
\text { were much higher }\end{array}$ \\
\hline French, DD $(2012)^{8}$ & 2007 & $\begin{array}{l}90 \text {-day rates of cataract procedure } \\
\text { complications requiring corrective } \\
\text { procedures }\end{array}$ & $\begin{array}{l}\text { VA had higher rates of corrective procedures } \\
\text { for complications }\end{array}$ \\
\hline Chakkera, HA $(2005)^{9}$ & 1991-2001 & $\begin{array}{l}\text { Kidney transplant graft failure and } \\
\text { patient survival after kidney transplant }\end{array}$ & $\begin{array}{l}\text { VA had higher graft failure and mortality } \\
\text { rates }\end{array}$ \\
\hline Rivard, PE (2010) ${ }^{10}$ & $2003-2004$ & Patient safety indicators (PSIs) & VA had higher rates of PSIs \\
\hline Rosen, AK (2005) ${ }^{11}$ & $2000-2001$ & Patient safety Indicators & $\begin{array}{l}\text { VA had higher rates of some PSIs and } \\
\text { lower for others }\end{array}$ \\
\hline
\end{tabular}

Published online October 11, 2016 
Corresponding Author: William B. Weeks, MD, PhD, MBA; The Dartmouth Institute, Lebanon, NH, USA (e-mail: wbw@dartmouth.edu).

\section{REFERENCES}

1. O'Hanlon C, Huang C, Sloss E, et al. Comparing VA and non-VA quality of care: a systematic review. J Gen Intern Med. 2016. doi:10.1007/211606016-3775-2.

2. Borzecki AM, Christiansen CL, Loveland S, Chew P, Rosen AK. Trends in the inpatient quality indicators: the Veterans Health Administration experience. Med Care. 2010;48:694-702.

3. Malhotra A, Vaughan-Sarrazin M, Rosenthal GE. Elderly veterans with dual eligibility for VA and Medicare services: where do they obtain a colonoscopy? Am J Manag Care. 2015;21:e264-e270.

4. Vaughan-Sarrazin MS, Wakefield B, Rosenthal GE. Mortality of Department of Veterans Affairs patients undergoing coronary revascularization in private sector hospitals. Health Serv Res. 2007;42:1802-1821.
5. Krein SL, Hofer TP, Kowalski CP, et al. Use of central venous catheterrelated bloodstream infection prevention practices by US hospitals. Mayo Clin Proc. 2007;82:672-678.

6. Fihn SD, Vaughan-Sarrazin M, Lowy E, et al. Declining mortality following acute myocardial infarction in the Department of Veterans Affairs health care system. BMC Cardiovasc Disord. 2009;9:44.

7. Bilimoria KY, Bentrem DJ, Tomlinson JS, et al. Quality of pancreatic cancer care at Veterans Administration compared with non-Veterans Administration hospitals. Am J Surg. 2007;194:588-593.

8. French DD, Margo CE, Campbell RR. Comparison of complication rates in veterans receiving cataract surgery through the Veterans Health Administration and Medicare. Med Care. 2012;50:620-626.

9. Chakkera HA, O'Hare AM, Johansen KL, et al. Influence of race on kidney transplant outcomes within and outside the Department of Veterans Affairs. J Am Soc Nephrol. 2005; 16:269-277.

10. Rivard PE, Elixhauser A, Christiansen CL, Shibei Z, Rosen AK. Testing the association between patient safety indicators and hospital structural characteristics in VA and nonfederal hospitals. Med Care Res Rev. 2010;67:321-341.

11. Rosen AK, Rivard P, Zhao S, et al. Evaluating the patient safety indicators: how well do they perform on Veterans Health Administration data? Med Care. 2005;43:873-884. 